Volume: 3

Issue: 1

Page: $19-27$

November 2016

\title{
Observed TEC Anomalies by GNSS Sites Preceding the Aegean Sea Earthquake of 2014
}

\author{
Mustafa Ulukavak*, Mualla Yalçınkaya \\ Department of Geomatics Engineering, Karadeniz Technical University, 61080, Trabzon
}

\begin{abstract}
In recent years, Total Electron Content (TEC) data, obtained from Global Navigation Satellites Systems (GNSS) receivers, has been widely used to detect seismo-ionospheric anomalies. In this study, Global Positioning System - Total Electron Content (GPS-TEC) data were used to investigate ionospheric abnormal behaviors prior to the 2014 Aegean Sea earthquake (40.305 $\mathrm{N}$ 25.453ㄹ, 24 May 2014, 09:25:03 UT, Mw:6.9). The data obtained from three Continuously Operating Reference Stations in Turkey (CORS-TR) and two International GNSS Service (IGS) sites near the epicenter of the earthquake is used to detect ionospheric anomalies before the earthquake. Solar activity index (F10.7) and geomagnetic activity index (Dst), which are both related to space weather conditions, were used to analyze these pre-earthquake ionospheric anomalies. An examination of these indices indicated high solar activity between May 8 and 15, 2014. The first significant increase (positive anomalies) in Vertical Total Electron Content (VTEC) was detected on May 14, 2014 or 10 days before the earthquake. This positive anomaly can be attributed to the high solar activity. The indices do not imply high solar or geomagnetic activity after May 15, 2014. Abnormal ionospheric TEC changes (negative anomaly) were observed at all stations one day before the earthquake. These changes were lower than the lower bound by approximately 10-20 TEC unit (TECU), and may be considered as the ionospheric precursor of the 2014 Aegean Sea earthquake.
\end{abstract}

$\underline{\text { Keywords }}$

Ionosphere, Total Electron Content, VTEC, Earthquake, Aegean Sea, GNSS

\section{Özet}

2014 Ege Denizi Depremi Öncesi GNSS İstasyonlarında Gözlemlenen TEC Anomalileri

Cilt: 3

Sayı: 1

Sayfa: $19-27$

Kasım 2016
Son yıllarda, Küresel Konumlandırma Uydu Sistemleri (GNSS) alıcılarından elde edilen Iyonosferik Toplam Elektron İçeriği (TEC) değerleri, sismik anomalileri tespit etmede artan bir şekilde kullanılmaktadır. Bu çalışmada, Küresel Konumlandırma sistemi - Toplam Elektron İçeriği (GPS-TEC) değişimleri kullanılarak 2014 Ege Denizi depremi (40.305 $\mathrm{N} 25.453^{\circ} \mathrm{E}, 24$ May 2014, 09:25:03 UT, Mw:6.9) öncesinde iyonosferik TEC te gerçekleşen anormal değişimler araştırılmıştır. Deprem merkez üssü yakınındaki Türkiye Sabit GNSS Ağı'na (TUSAGA-Aktif) ait üç istasyon ve Uluslararası GNSS Servisi'ne (IGS) ait iki istasyondan elde edilen veriler kullanılarak deprem öncesi iyonosferik anomaliler tespit edilmiştir. Uzay iklim koşullarıyla ilişkili olan Güneş Aktivitesi Indeksi (F10.7) ve Jeomanyetik Aktivite Indeksi (Dst), deprem öncesi iyonosferik anomalileri analiz etmek için kullanılmıştır. Bu değerler incelendiğinde 8-15 Mayıs 2014 tarihleri arasında yüksek güneş aktivitesinin meydana geldiği görülmüştür. Düşey Toplam Elektron İçeriğindeki (VTEC) ilk anlamlı artış (pozitif anomali) depremden 10 gün önce 14 Mayls 2014 tarihinde tespit edilmiştir. Bu değişim büyük ihtimalle yüksek güneş aktivitesinden dolayı gerçekleşmiştir. İndis değerleri, 15 Mayls 2014 tarihinden sonra yüksek güneş aktivitesi veya Jeomanyetik aktivitenin gerçekleşmediğini vurgulamıştır. Depremden bir gün önce her istasyona ait iyonosferik TEC değişimlerinde anormal değişimler (negatif anomali) görülmüştür. Alt sinır değerden yaklaşık 10-20 TEC birimi (TECU) düşük olan bu değişimlerin 2014 Ege Denizi depreminin öncülü olabileceği düşünülmektedir.

Anahtar Sözcükler

İyonosfer, Toplam Elekron İçeriği, VTEC, Deprem, Ege Denizi, GNSS

\footnotetext{
* Corresponding Author:
}

mulukavak@ktu.edu.tr, mualla@ktu.edu.tr 


\section{Introduction}

Recently, data obtained from dual-frequency GNSS receivers have been used both for ionospheric studies and accurate positioning. Dual-frequency GNSS receivers are used to derive TEC data, thereby providing users with more information about the upper atmosphere. The great Alaska earthquake, in 1964 was the first earthquake whose seismic-ionospheric anomalies were investigated (Davies and Baker 1965, Leonard and Barnes 1965). Earthquake precursors have been a research interest for many scientists. The relationship between seismic events and unforeseen variations in ionospheric activity has been the main topic of several studies (Parrot et al. 1993; Liperovsky et al. 2000; Afraimovich et al. 2001; Pulinets et al. 2003).

Satellite and ground-based instruments have been used in various studies to examine seismo-ionospheric effects. The ionospheric effects that relate to the Northridge earthquake were measured by Calais and Minster (1998) by using GPS-TEC data. They concluded that TEC variations were due to acoustic gravity waves. Pre-earthquake ionospheric anomalies were observed 15 days before and after some earthquakes (Calais and Minister 1998). Liu et al. (2004) investigated the earthquakes that occurred in Taiwan from 1999 to 2002, with magnitudes greater than or equal to 6. The ionospheric TEC decreased drastically 1 to 5 days prior to the earthquakes. Otsuka et al. (2006) determined the GPS-TEC variations after the powerful earthquake that occurred in West Sumatra, Indonesia on December 26, 2004. They concluded that the TEC increased by $1.6-6.9$ TEC units (TECU) north of the epicenter. Hasbi et al. (2011) examined ionospheric perturbations prior to the earthquakes (of $\mathrm{M}>=7.0$ ) in the Sumatra area by using GPS data and Challenging Minisatellite Payload (CHAMP) data. They detected some positive and negative anomalies that range from a few hours to 6 days prior to the earthquakes. Le et al. (2011) investigated the ionospheric anomalies by using Global Ionosphere Map TEC (GIM-TEC) data obtained from the global ionosphere maps. The ionospheric anomalies, which are observed near epicenters before earthquakes, have attracted considerable attention. Hence, various studies have reported on pre-earthquake ionospheric anomalies observed for some special earthquake events (Calais and Minster 1995; Chmyrev et al. 1997; Silina et al. 2001; Liu et al. 2000, 2006, 2008, 2010, 2011; Plotkin 2003; Rios et al. 2004; Pulinets and Boyarchuk 2004; Trigunait et al. 2004; Hobara and Parrot 2005; Liperovskaya et al. 2006; Krankowski et al. 2006; Zakharenkova et al. 2006, 2007, 2008; Singh and Singh 2007; Zhao et al. 2008; Lin et al. 2009; Zhou et al. 2009; Hsiao et al. 2010; Lin 2010, 2012; Jyh-Woei 2011; Yao et al. 2012).

This study investigates the TEC anomalies at GNSS sites prior to the 2014 Aegean Sea earthquake. Section 2 describes the derivation of the TEC data from GNSS observations, Section 3 explains the analysis of the daily TEC variations, and Section 4 explains the analysis of the precursors observed before the Aegean Sea earthquake. The conclusions are given in Section 5.

\section{Obtaining TEC Data from GNSS Observations}

Ionospheric TEC can be quantified either by using the geometry-free linear combination of the code (P) or by using carrier phase $(\Phi)$ measurements (Schmidt et al. 2008). For pseudo-range measurements, the geometry-free linear combination, which is calculated by subtracting the $\mathrm{P}_{2}$ code measurements from the $\mathrm{P}_{1}$ code measurements, is given as

$$
P_{4, u}^{m}=P_{1}-P_{2}=A\left(\frac{1}{f_{1}^{2}}-\frac{1}{f_{2}^{2}}\right) S T E C_{u}^{m}+D C B^{m}+D C B_{u}
$$

where $f_{1}$ and $f_{2}$ are the carrier frequencies of L1 and L2 signals of GPS satellites, respectively; $A=40.3 \mathrm{~m}^{3} / \mathrm{s}^{2}$ and $S_{T E C}^{m}$ denotes the Slant Total Electron Content (STEC) in units of TECU $\left(1 \mathrm{TECU}=10^{16}\right.$ electrons $\left./ \mathrm{m}^{2}\right)$ on the slant signal path that combines the receiver $u$ and the satellite $m$; and $D C B^{m}$ and $D C B_{u}$ are differential code biases (DCBs) of pseudo-range measurements defined for the satellite and the receiver, respectively. For carrier phase measurements, the geometry-free linear combination can be obtained by subtracting the $\Phi_{2}$ phase observations from $\Phi_{1}$ phase observations as follows:

$$
\begin{aligned}
\Phi_{4, u}^{m} & =\Phi_{1}-\Phi_{2} \\
& =-A\left(\frac{1}{f_{1}^{2}}-\frac{1}{f_{2}^{2}}\right) S T E C_{u}^{m}+I F B^{m}+I F B_{u}+\Delta N_{u, 4}^{m}
\end{aligned}
$$

where, $I F B^{m}$ and $I F B_{u}$ are the inter-frequency biases for the carrier-phase measurements of the satellite and the receiver, respectively, The combined ambiguity term $\Delta N_{u, 4}^{m}$ in Equation (2) is defined as

$\Delta N_{u, 4}^{m}=\lambda_{1} N_{u, 1}^{m}-\lambda_{2} N_{u, 2}^{m}$

where, $\mathrm{N}_{u, 1}^{m}$ and $\mathrm{N}_{u, 2}^{m}$ denote the integer phase ambiguities, and, $\lambda_{1}, \lambda_{2}$ are the wavelengths that correspond to $f_{1}$ and $f_{2}$ frequencies, respectively (Komjathy 1997; Liao 2000; Leick 2004; Dach et al. 2007; Jin et al. 2012).

Differential code biases need to be known in order to obtain the unbiased slant TEC. DCBs are provided for some IGS stations for certain dates in the IONEX files, which are provided mostly by Jet Propulsion Laboratory (JPL), Center for Orbit Determination in Europe (CODE), and European Space Agency (ESA) Ionosphere Associate Analysis Centers. STEC can be computed by eliminating the DCBs from the geometry-free linear combination given in Equation (1).

$$
\operatorname{STEC}_{u}^{m}(n)=\frac{1}{A}\left(\frac{f_{1}^{2} f_{2}^{2}}{f_{2}^{2}-f_{1}^{2}}\right)\left[P_{4, u}^{m}(n)-\left(D C B^{m}+D C B_{u}\right)\right]
$$

where the index $n$ denotes the index of time sample ranging from 1 to $N$ which is the total number of time samples in a record. A typical GNSS receiver records data on every 30 seconds. For a continuous 24-hour period, the maximum value for $N$ is 2880 . If the DCB values for satellites and receiver are known, then the STEC can be computed for each arc by using Equation (4). However, the noise level in P4 measurements is higher than $\Phi_{4}$. Thus $\Phi_{4}$ data are 
usually fitted to the $P_{4}$ to smooth the $P_{4}$ observations by taking advantage of less noisy carrier-phase measurements. Several fitting algorithms have been proposed in the literature (Lanyi and Roth 1988; Jakowski et al. 1996; Komjathy and Langley 1996; Otsuka et al. 2002; Jin et al. 2012). Leveling or fitting of $\Phi_{4}$ to $P_{4}$ is usually achieved by defining a constant offset for each continuous arc of phase measurement as follows:

$$
B^{m}=\frac{1}{N_{m e}} \sum_{n_{m e}=1}^{N_{m e}}\left(P_{4, u}^{m}\left(n_{m e}\right)+\Phi_{4, u}^{m}\left(n_{m e}\right)\right)
$$

where $B^{\mathrm{m}}$ denotes the constant offset value for the $\mathrm{m}^{\text {th }}$ satellite, $N_{\text {me }}$ is the total number of samples in each phasecontinuous arc and $n_{m e}$, is the time duration of the total samples in each arc. Each cycle-slip or phase discontinuity starts another constant offset calculation. The constant offset value $B^{\mathrm{m}}$ is combined with the $\Phi_{4}$ in Equation (6) to obtain the STEC as follows:

$$
\operatorname{STEC}_{u}^{m}(n)=\frac{1}{A}\left(\frac{f_{1}^{2} f_{2}^{2}}{f_{2}^{2}-f_{1}^{2}}\right)\left(B^{m}-\Phi_{4, u}^{m}(n)-\left(D C B^{m}+D C B_{u}\right)\right)
$$

Once the STEC is computed, the VTEC can be obtained by using a thin-shell approximation (Klobuchar 1986) of the single layer ionosphere model for which the relation between STEC and VTEC is given as

$$
M\left(z_{m}(n)\right)=\frac{\operatorname{STEC}_{u}^{m}(n)}{\operatorname{VTEC}_{u}^{m}(n)}
$$

where, $Z_{m}(n)$ is the satellite zenith angle at the receiver position and the mapping function $M(\mathrm{z})$ is defined as

$$
M(z)=\frac{1}{\cos z^{\prime}}=\frac{1}{\sqrt{1-\sin ^{2} z^{\prime}}}, \quad \sin z^{\prime}=\frac{R}{R+H} \sin (\alpha z)
$$

where $z^{\prime}$ is the zenith angle at the ionospheric pierce point (IPP) where the line-of-sight between the satellite and the ground receiver intersects the thin shell; $R$ is the earth radius $(6,378.137 \mathrm{~km}) ; \alpha=0.9886$ is a scaling factor of the modified single layer mapping function (Schaer 1999) and $H$ is the ionospheric shell height $(350 \mathrm{~km})$ (Mannucci et al. 1993; Langley et al. 2002; Rao et al. 2006; Spogli et al. 2013; Chakraborty et al. 2014).

The DCB values of the satellites and some other receivers are available in the final daily IGS IONEX files. The unknown DCB values of the stations can also be estimated as daily constants via using the regional VTEC modeling based on spherical harmonic functions (Jin et al. 2012). Jin et al. (2012) stated that the order of spherical harmonics expansion depends on the area. Spherical harmonics expansions can be $4^{\text {th }}, 8^{\text {th }}$, and $15^{\text {th }}$ order for the regional, continental, and global size, respectively. Then, the calibrated STEC variations are obtained by removing the estimated DCBs from each satellite arc [in Equation (6)], and VTEC values are determined by employing Equation (7) for each continuous arc.

\section{Analysis of Daily GPS-TEC Variations}

In the previous section, calibrated VTEC values for each satellite arc are extracted. In order to monitor anomalous days, the VTEC values at IPP points should be utilized to get daily VTEC variation over each ground station. In this study, during a 24-hour run, the hourly VTEC over each station is represented by a second-order polynomial surface model (Durmaz and Karslioglu 2014).

$$
\begin{aligned}
\operatorname{VTEC}\left(\varphi_{I P P}, s_{I P P}\right) & =a_{0}+a_{1} \varphi_{I P P}+a_{2} s_{I P P}+a_{3} \varphi_{I P P}^{2} \\
& +a_{4} \varphi_{I P P} s_{I P P}+a_{5} s_{I P P}^{2}
\end{aligned}
$$

where, $\varphi_{I P P}$ and $S_{I P P}$ are the spherical coordinates of the IPP in a sun-fixed reference frame, and $a_{0}, a_{1}, a_{2}, a_{3}, a_{4}$ and $a_{5}$ are the polynomial surface coefficients. According to Equation (9), the hourly unknown polynomial surface coefficients are estimated via the least-squares method (LSE). For an hourly estimation of polynomial surface coefficients, the data window can be set to 120 epochs ( 60 epochs before and after each hour). The hourly VTEC values for each station are then calculated by substituting the sunfixed spherical coordinates of each station in Equation (9) alongside with the estimated polynomial surface coefficients. Insufficient data will cause problems when estimating the hourly VTEC value. Thus, the missing VTEC values above the stations should be completed by interpolating the grid TEC data obtained from IGS IONEX files (Schaer et al. 1998).

Anomalous variation in TEC was determined by using the quartile-based statistical analysis method, which is similar to that used by Liu et al. (2009). Before using the quartile-based statistical analysis method, moving median (M) values of GPS-TEC were calculated. Then, the first (or lower: LQ) and third (or upper: UQ) quartiles were calculated. Assuming that the GPS-TEC values are in normal distribution with mean $(\mathrm{m})$ and standard deviation $(\sigma)$, the excepted values of $M$ and LQ or UQ are m and $1.34 \sigma$, respectively (Klotz and Johnson 1983). The lower bound (LB) and upper bound (UB) are calculated as $\mathrm{LB}=\mathrm{M}-1.5(\mathrm{M}-\mathrm{LQ})$ and $\mathrm{UB}=\mathrm{M}+1.5(\mathrm{UQ}-\mathrm{M})$, respectively. Anomalous variation can be observed when the value of the observed GPS-TEC is greater than UB or smaller than the associated LB (Liu et al. 2009). For example, the VTEC values of the first 15 days were used to generate the median, upper, and lower bounds for the 16th day. Similarly, 15 days of VTEC data between the 2 nd and $16^{\text {th }}$ day were used to generate bounds for the $17^{\text {th }}$ day. Determination of $\mathrm{UB}$ and LB continues in this manner until the end of the data. Each particular day is marked anomalous when more than one-third of data ( 8 hours are anomalous in a day) is greater or smaller than the upper and lower bounds.

\section{Observed Precursors of the Aegean Sea Earthquake}

In this study, a strong Mw 6.9 earthquake that occured in the Aegean Sea at 09:25:03 UT on May 24, 2014 (http://earthquake.usgs.gov) was investigated. To reveal the ionospheric precursors for the Aegean Sea earthquake, we extracted the anomalous VTEC variations by using the GPS data from selected Turkish Continuously Operating Reference Stations (CORS) Network (CORS-TR) and IGS sites in the vicinity of the earthquake epicenter. Two indices (F10.7 and Dst) that relate to the space weather conditions 
were used to analyze these pre-earthquake ionospheric anomalies. Anomalous variation in TEC was determined by using the quartile-based statistical analysis method (Liu et al. 2009). Liu et al. (2009) used GIM-TEC (2-hour resolution) data for the earthquake epicenter. In the current study, we estimated GPS-TEC data (1-hour resolution), which were obtained from the GNSS stations near the epicenter of the earthquake, by using surface polynomial fitting.

According to Dobrovolsky et al. (1979), the radius of an earthquake preparation zone is given as

$$
\rho=10^{0.43^{*} M} \mathrm{~km}
$$

where $\rho$ is the radius of the earthquake preparation zone, and $M$ is the earthquake magnitude on the moment magnitude scale. The radius of the earthquake preparation zone for an Mw 6.9 earthquake extends approximately $926.82 \mathrm{~km}$ from the epicenter. The geographic locations of 3 CORS sites in Turkey (AYVL, IPSA and YENC) and 2 IGS sites (DYNG and ORID) in Greece and Macedonia are given in Figure 1.

Hourly GPS-TEC data for the days between April 25 and June 5, 2014 were processed by following the methodology explained in Section 2. Raw observations of IGS stations in Receiver INdependent EXchange Format (RINEX) files, SP3 (Precise satellite orbits) files, and IONEX (Ionospheric TEC maps and Satellite DCBs) files were obtained from the Crustal Dynamics Data and Information System (CDDIS) GNSS data and products archive via the link ftp://cddis. gsfc.nasa.gov . CORS-TR RINEX files were downloaded from the General Directorate of Land Registry and Cadastre (TKGM) Turkish CORS Network archives.

Cycle slips and gross errors in the carrier phase observations should be removed before using the carrier phase observations to smooth the pseudo-range observations. The cycle- slips within the observations in the RINEX files were detected and phase discontinuities were removed by using the smoothing algorithm implemented in the Bernese v5.0 software. The satellite DCB estimates in the final IGS IONEX files were reused as unknown quantities whereas the receiver DCBs were estimated as daily constants inside a regional VTEC modeling by using M_DCB software with smoothed RINEX files (Jin et al. 2012). The VTEC model applied was based on spherical harmonics. With the size of the study area and the number of the GNSS receivers taken into consideration, maximum order of the spherical harmonics expansion was set to the 4 in the M_DCB software. Elevation

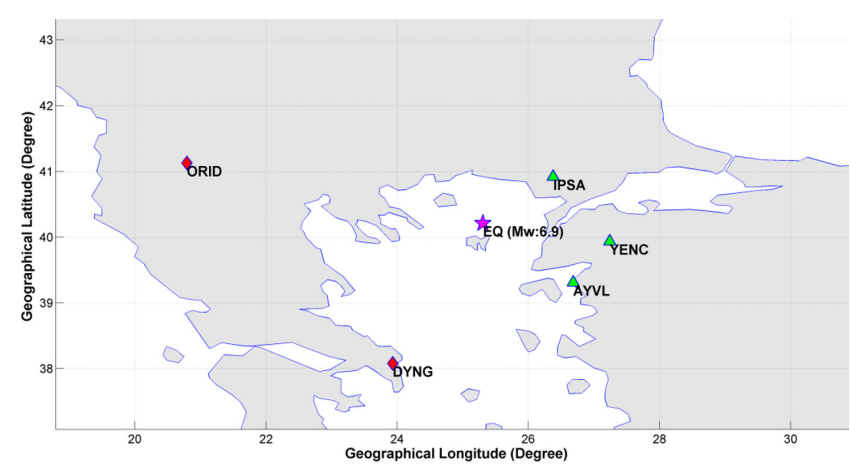

Figure 1: Geographic locations of the CORS-TR network stations (triangle), IGS Sites (diamond), and the epicenter of the Aegean Sea earthquake (star).

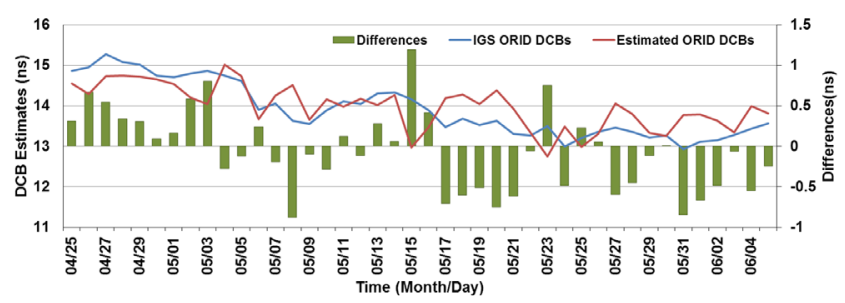

Figure 2 : Comparison between the daily receiver DCB estimates of the ORID station and IGS IONEX file values between the dates April 25 and June 5, 2014 (blue line: IGS DCBs from IONEX files; red line: estimated ORID DCBs).

cut-off angle, which is used to mitigate the multipath effects on GPS signals, was set to 10 degrees. The calibrated STEC variations were obtained by removing the estimated DCBs from each satellite arc. Then, STEC values with the associated mapping function were used to obtain VTEC values for each continuous arc. All computations and statistical procedures were carried out within the MATLAB software. All maps and graphics were plotted in the MATLAB environment.

In order to check the reliability of DCB estimations, the estimated DCBs of ORID station were compared with the estimates in the IGS IONEX files. ORID station was used because common DCB values of the same station are included in the IGS final IONEX file. The differences between the estimated daily receiver DCBs and IGS IONEX DCBs of ORID station are shown in Figure 2.

A comparison between the DCBs estimated from the ORID station and the DCBs from the IGS IONEX files revealed a difference of less than $1 \mathrm{~ns}$. DCB differences are higher than $1 \mathrm{~ns}(1.12 \mathrm{~ns})$ only for May 15, 2014. The calculated RMS (Root Mean Square) of differences of the estimated ORID IGS receiver DCBs and value of the IGS IONEX file is $\pm 0.24 \mathrm{~ns}$. The results indicate that the estimated ORID site receiver DCBs may be considered reliable.

In addition to this comparison, the GPS-TEC values were compared with the VTEC values obtained from IGS final IONEX files. To check the reliability of the calculated VTEC values of the IGS and CORS-TR stations, the daily mean values of differences and RMS of differences between the GPS-TEC and IGS final IONEX file values were calculated for each IGS and CORS-TR station (Figure 3).

The accuracy of IGS IONEX TEC values is defined in the range of 2-8 TECU (https://igscb.jpl.nasa.gov/components/ prods.html). Figure 3 shows that the calculated mean and RMS of GPS-TEC values are within the acceptable ranges and can be considered reliable.

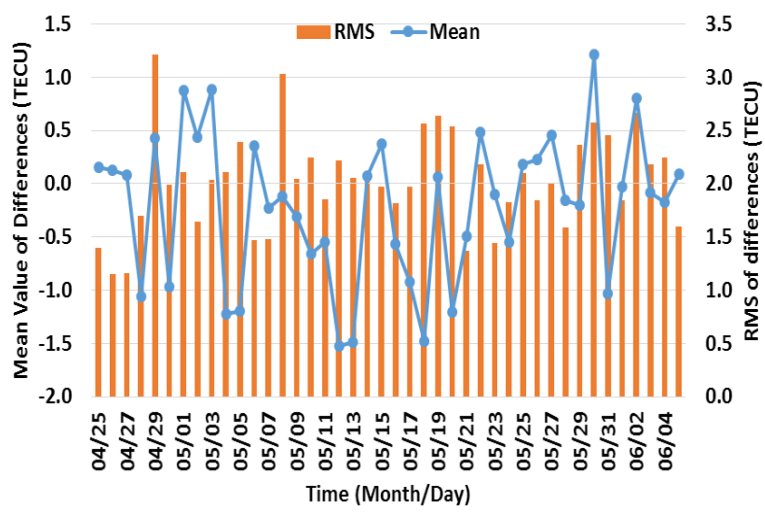

(a) AYVL CORS-TR Station 

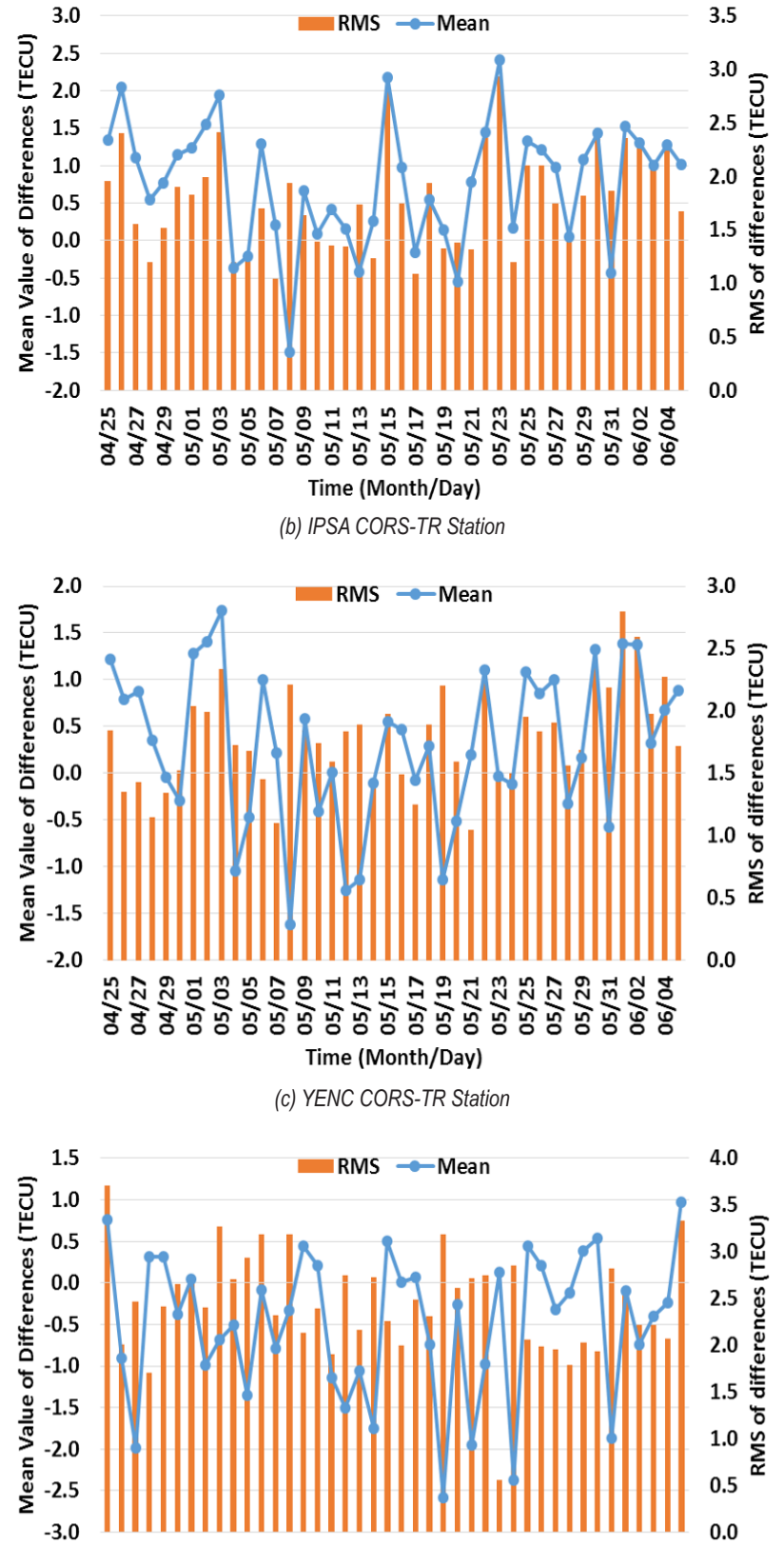

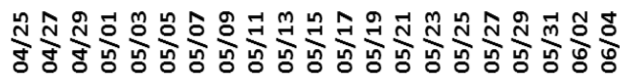
Time (Month/Day)

(d) DYNG IGS Station

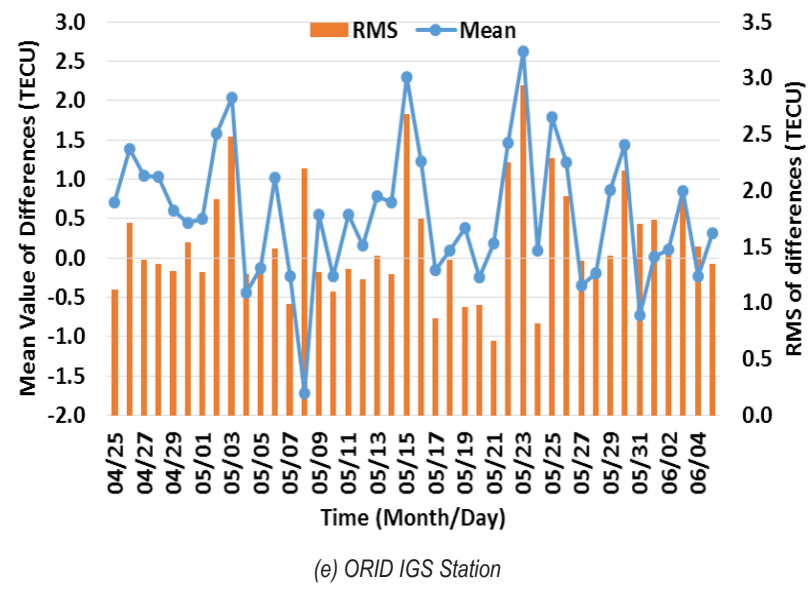

Figure 3 : Daily mean values and RMS of differences between the GPS-TEC and VTEC from IGS IONEX files.
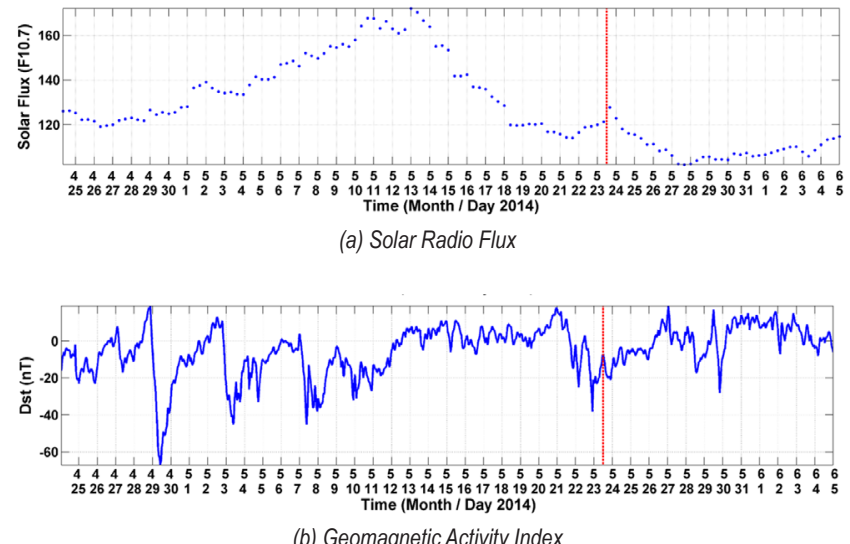

Figure 4 : Variations in the solar radio flux and the geomagnetic activity index between April 25 and June 5, 2014 (vertical red line: Aegean Sea earthquake).

Space weather conditions must be taken into account when discussing the relationship between ionospheric anomalies and earthquakes. We monitored the solar sctivity index $(\mathrm{F} 10.7 \mathrm{~cm})$ and geomagnetic activity index (Dst) to mark anomalies which can potentially be attributed to space weather conditions. Dst indices and solar radio flux values for the time interval between April 25, 2014 and June 5, 2014 were obtained from http://swdcwww.kugi.kyoto-u. ac.jp/index.html , and http://www.spaceweather.ca/solarflux/ sx-5-eng.php, respectively (Figure 4).

Vitinsky et al. (1986), Bruevich et al. (2014) and Coley et al. (2014) pointed out that solar activity may be classified in terms of the F10.7 index. Solar flux less than 150 sfu indicates low solar activity, while solar flux values higher than $150 \mathrm{sfu}$ indicate high solar activity. According to Figure 4a, the solar flux started to increase gradually on May 8, 2014, peaked on May 14, 2014 (172.1 sfu), and decreased gradually over time. The solar flux values were less than 150 solar flux unit (sfu) for the last 8 days (May 15-23, 2014) before and 12 days (May 24 -June 5, 2014) after the earthquake.

Kamide et al. (1998), Rozhnoi et al. (2004) and Contadakis et al. (2012) pointed out that geomagnetic storms are classified as weak $\left(\right.$ Dst $\left._{\min }>-50 \mathrm{nT}\right)$, moderate $(-50>$ $\left.\mathrm{Dst}_{\text {min }}>-100 \mathrm{nT}\right)$, and intense (Dst ${ }_{\text {min }}<-100 \mathrm{nT}$ ) according to the magnitude of the storms. As in Figure 4b, the Dst values decreased drastically to $-67 \mathrm{nT}$ (nanotesla) on April 30, 2014. The Dst values are higher than $-50 \mathrm{nT}$ for the time interval May 1, 2014 and June 5, 2014, which indicates weak geomagnetic activity for this time period.

Upper, lower, and median values, and the daily variation of the GPS-TEC were calculated based on the methodology in Section 3 (Figure 5).

Solar activity values were high between May 8-15, 2014. Solar activity peaked 10 days (May 14, 2014) before the earthquake. The GPS-TEC values, which were greater than UB (black colored areas) within this time interval, may lead to misinterpretation of seismo-ionospheric effects of the Aegean Sea earthquake. However, space-weather conditions were quiet for the days after May 15, 2014, and these days had suitable space weather conditions for investigation of seismo-ionospheric effects of the Aegean Sea earthquake. Figure 5 clearly shows that, for all sites, VTEC values were 10-20 TECU lower than the LB (red 

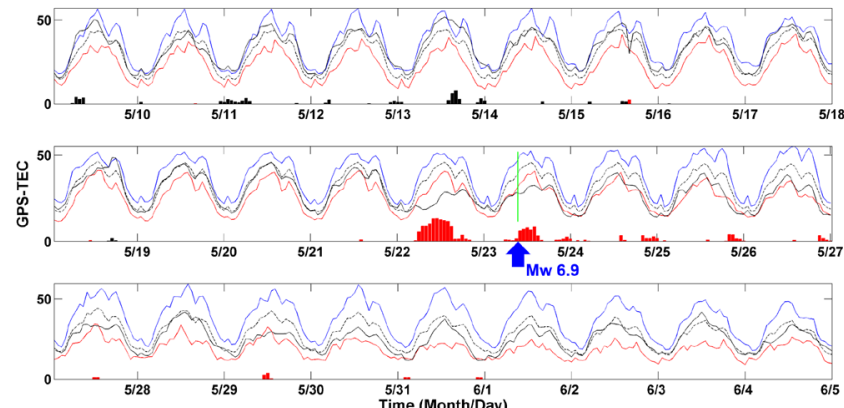

(a) AYVL CORS-TR Station
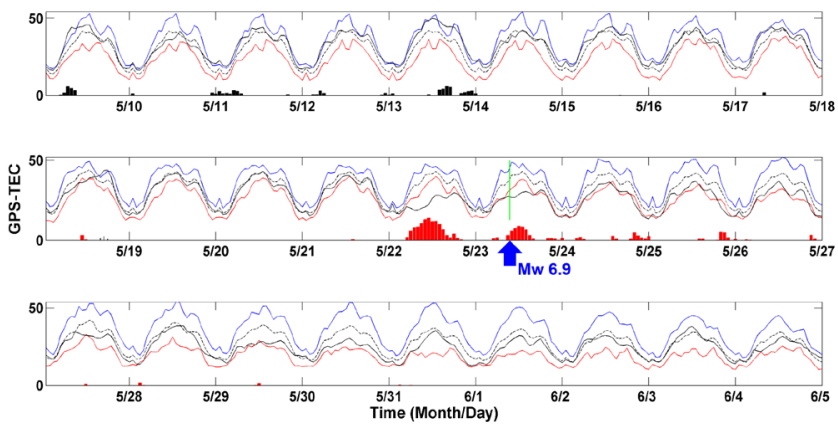

(b) IPSA CORS-TR Station
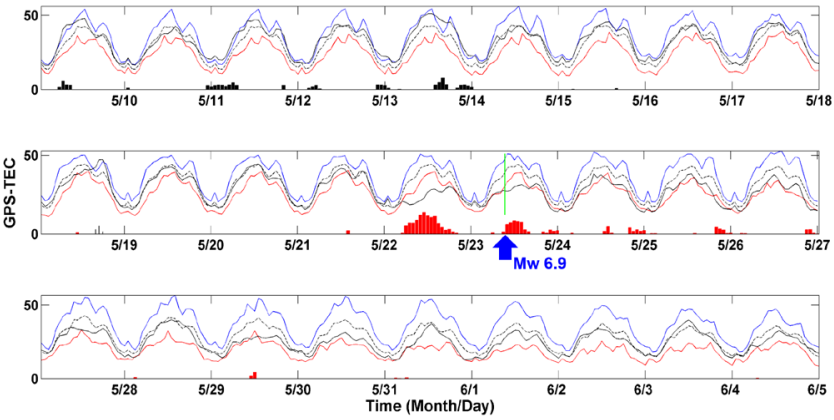

(c) YENC CORS-TR Station
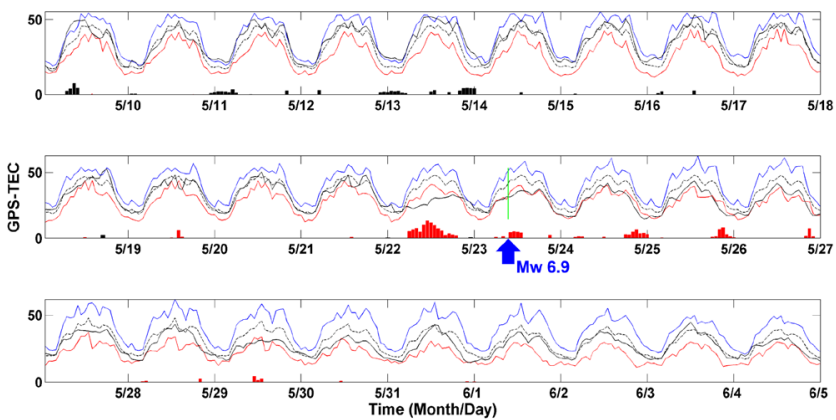
(d) DYNG IGS Site
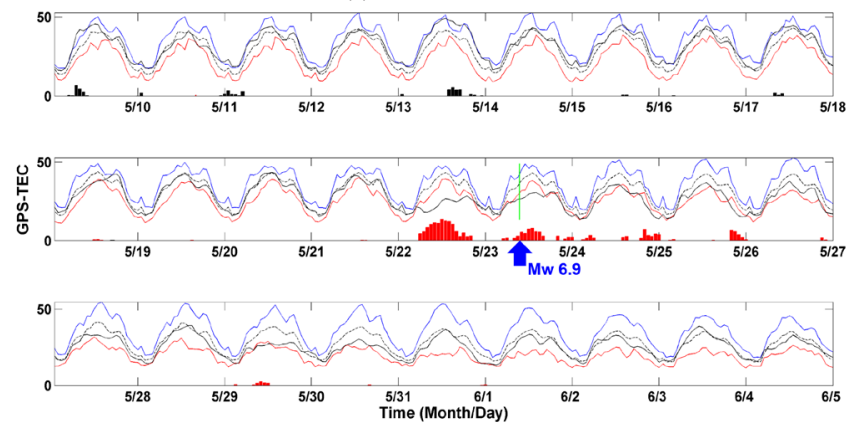

(e) ORID IGS Site

Figure 5 : GPS-TEC variations over each stations, the upper (enhancement), lower (reduction), and median anomalies before and after the Aegean Sea earthquake. (blue upward arrow: the earthquake occurrence moment; black line: estimated GPS-TEC variations; blue line: upper bound (UB); red line: lower bound (LB); dashed black line: median values (M); black colored areas: VTEC minus UB; red colored areas: LB minus VTEC).

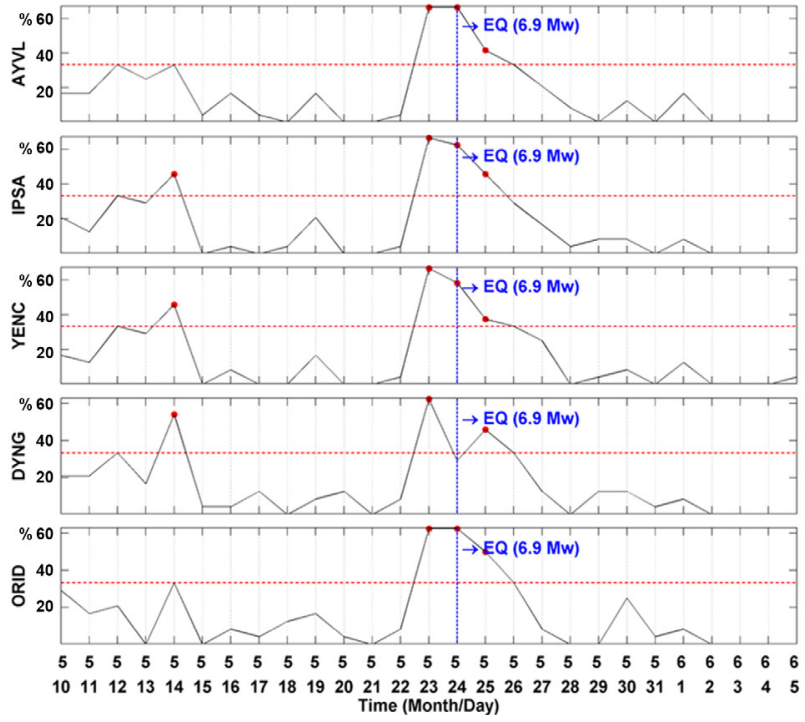

Figure 6: Percentage of the upper and lower anomalous days between the dates May 10 -June 5, 2014 (dashed horizontal red line: limit percentage of anomalous VTEC of the day; red dots: exceeded the limit values of the upper and lower anomalous days; dashed vertical gray line: end of the solar activity day (15 May 2014), dashed vertical blue line: day of the earthquake.

colored areas) on the day (May 23, 2014) before the earthquake.

The number of VTEC anomalies was determined from the percentage of daily VTEC anomalies. The limit percentage of anomalous VTEC was determined as $\sim 33 \%$ ( 8 hours are anomalous in a day) (Figure 6).

The percentage of anomalous days before and after the earthquake is shown in Figure 6. The percentage of anomalous VTEC variations was $66.67 \%$ for AYVL, IPSA, and YENC CORS-TR stations, and $62.50 \%$ for DYNG and ORID IGS stations on May 23, 2014. All calculated percentages are given in Table 1.

As shown in Table 1, the percentage calculated for May 14, 2014 could be related to the solar activity, which ended on May 15, 2014. On the other hand, the percentages calculated for May 23, 24, and 25 may be related more to the Aegean Sea earthquake than the space weather conditions.

\section{Conclusions}

This study investigated the ionospheric TEC anomalies before the 2014 Aegean Sea earthquake. The solar activity (F10.7) and geomagnetic activity (Dst) indices were examined. Ionospheric TEC values were determined by using the GNSS data. A comparison of the sun activity revealed high solar activity between May 8 and 15, 2014. Ionospheric TEC values greater than UB within the same time interval and peaked on May 14, 2014 or 10 days before the earthquake. These anomalies are more likely to be attributed to the space- weather conditions. Therefore, ionospheric

Table 1. Percentage of anomalous VTEC variations of all stations

\begin{tabular}{ccccc} 
Station & $14^{\text {th }}$ May & $23^{\text {th }}$ May & $2^{\text {th }}$ May & $25^{\text {th }}$ May \\
AYVL & - & 66.67 & 66.67 & 41.67 \\
\hline IPSA & 45.83 & 66.67 & 62.50 & 45.83 \\
YENC & 45.83 & 66.67 & 58.33 & 37.50 \\
DYNG & 54.17 & 62.50 & - & 45.83 \\
ORID & - & 62.50 & 62.50 & 50.00
\end{tabular}


TEC values were examined for the days between May 15 and June 5, 2014, during which solar activity was low. The VTEC values on May 23, 24, and 25, 2014 were less than the LB values calculated for the same days by approximately 10-20 TECU. The first abnormal change in TEC values within the quiet period of solar activity was detected one day before the earthquake (May 23, 2014). In this regard, the abnormal change may be considered as the ionospheric precursor of the 2014 Aegean Sea earthquake.

The development of GNSS technology and assimilation techniques enables us to further improve our understanding of the ionosphere. In the near future, GPS-TEC will increasingly be utilized to discover the mechanism of seismo-ionospheric coupling.

This paper focuses only on demonstrating the ionospheric variability prior to the Aegean Sea earthquake. The physical mechanism of seismo-ionospheric effects of this earthquake will be examined in future studies.

Acknowledgements. The authors would like to thank the data centers, the General Directorate of Land Registry and Cadastre (TKGM) for providing the GPS recordings of Turkish CORS Network and International GNSS Service for providing the RINEX and SP3 data, International GNSS Service (IGS) for providing the IONEX files, the Data Analysis Center for Geomagnetism and Space Magnetism Graduate School of Science, Kyoto University (WDC) for providing the geomagnetic data and The Canadian Space Weather Forecast Centre (CSWFC) in Ottawa for providing the Solar radio flux data. The author would like to thank the editor-in chief and two anonymous reviewers for their valuable comments and suggestions on improving the quality of the paper. The authors would also like to thank Asst. Prof. Dr. Emine Tanir Kayikci and Res. Asst. Volkan Yilmaz for the translation and grammar review of this paper.

\section{References}

Afraimovich E.L., Kosogorov E.A., Perevalova N.P., Plotnikov A.V., (2001), The use of GPS arrays in detecting shockacoustic waves generated during rocket launchings, Journal of Atmospheric and Solar-Terrestrial Physics, 63, 1941-1957.

Bruevich E.A., Bruevich V.V., Yakunina G.V., (2014), Changed relation between solar $10.7-\mathrm{cm}$ radio flux and some activity indices which describe the radiation at different altitudes of atmosphere during cycles 21-23, Journal of Astrophysics and Astronomy, 35, 1-15.

Calais E., Minster J.B., (1995), GPS Detection of ionospheric perturbations following the January 17, 1994, Northridge earthquake, Geophysical Research Letters, 22, 1045-1048.

Calais E., Minster J.B., (1998), GPS, earthquakes, the ionosphere, and the space shuttle, Physics of the Earth and Planetary Interiors, 105, 167-181.

Chakraborty M., Kumar S., De B.K., Guha A., (2014), Latitudinal characteristics of GPS derived ionospheric TEC: a comparative study with IRI 2012 model, Annals of Geophysics, doi:10.4401/ ag-6438.

Chmyrev V.M., Isaev N.V., Serebryakova O.N., Sorokin V.M., Sobolev Y.P., (1997), Small-scale plasma inhomogeneities and correlated ELF emissions in the ionosphere over an earthquake region, Journal of Atmospheric and Solar-Terrestrial Physics, 59, 967-974.
Coley W.R., Stoneback R.A., Heelis R.A., Hairston M.R., (2014), Topside equatorial zonal ion velocities measured by C/NOFS during rising solar activity, Annales Geophysicae, 32, 69-75.

Contadakis M., Arabelos D., Pikridas C., Spatalas S., (2012), Total electron content variations over southern Europe before and during the M 6.3 Abruzzo earthquake of April 6, 2009, Annals of Geophysics, 55, 83-93.

Dach R., Hugentobler U., Fridez P., Meindl M., (2007), Manual of Bernese GPS Software Version5.0, Astronomical Institute, University of Bern, Bern.

Davies K., Baker D.M., (1965), Ionospheric effects observed around time of Alaskan earthquake of March 28 1964, Journal of Geophysical Research, 70, 2251-2253.

Dobrovolsky I.P., Zubkov S.I., Miachkin V.I., (1979), Estımation of the size of earthquake preparation zones, Pure and Applied Geophysics, 117, 1025-1044.

Durmaz M., Karslioglu M.O., (2014), Regional Vertical Total Electron Content (VTEC) modeling together with satellite and receiver Differential Code Biases (DCBS) using Semi-Parametric Multivariate Adaptive Regression B-splines (SP-BMARS), Journal of Geodesy, doi: 10.1007/s00190-014-0779-8.

Hasbi A.M., Ali M.A.M., Misran N., (2011), Ionospheric variations before some large earthquakes over Sumatra, Natural Hazards and Earth System Sciences, 11, 597-611.

Hobara Y., Parrot M., (2005), Ionospheric perturbations linked to a very powerful seismic event, Journal of Atmospheric and SolarTerrestrial Physics, 67, 677-685.

Hsiao C.C., Liu J.Y., Oyama K.I., Yen N.L., Liou Y.A., Chen S.S., Miau J.J., (2010), Seismo-ionospheric precursor of the 2008 Mw7.9 Wenchuan earthquake observed by FORMOSAT-3/ COSMIC, GPS Solutions, 14, 83-89.

Jakowski N., Sardon E., Engler E., Jungstand A., Klahn D., (1996), Relationships between GPS-signal propagation errors and EISCAT observations. Annales Geophysicae, 14, 1429- 1436.

Jin R., Jin S.G., Feng G.P., (2012), M_DCB: Matlab code for estimating GNSS satellite and receiver differential code biases, GPS Solutions, 16(4), 541-548, doi: 10.1007/s10291-012-02793.

Jyh-Woei L., (2011), Use of principal component analysis in the identification of the spatial pattern of an ionospheric total electron content anomalies after China's May 12, 2008, M=7.9 Wenchuan earthquake, Advances in Space Research, 47, 198389.

Kamide Y., Yokoyama N., Gonzalez W., Tsurutani B.T., Daglis I.A., Brekke A., Masuda S., (1998), Two-step development of geomagnetic storms, Journal of Geophysical Research-Space Physics, 103, 6917-21.

Klobuchar J., (1986), Design and characteristics of the GPS ionospheric time-delay algorithm for single-frequency users, In: Procedings of the IEEE Position Location and Navigation Symposium (Las Vegas, November 4-7).

Klotz S., Johnson N.L. (Eds.), (1983), Encyclopedia of Statistical Sciences, John Wiley and Sons.

Komjathy A., (1997), Global ionospheric total electron content mapping using the global positioning system, Ph.D. Thesis, Dept. of Geodesy and Geomatics Engineering Technical Report No. 188. Univ. of New Brunswick, Fredericton, New Brunswick, Canada.

Komjathy A., Langley R., (1996), An assesment of predicted and measured ionospheric total electron content using a regional GPS network. paper presented at Nat. Tech. Meet., Inst. of Nav., Santa Monica, CA 22-24 January.

Krankowski A., Zakharenkhova I.E., Shagimuratov I.I., (2006), Response of the ionosphere to the Baltic Sea earthquake of 21 September 2004, Acta Geophysica, 54, 90-101. 
Langley R., Fedrizzi M., Paula E., Santos M., Komjathy A., (2002), Mapping the low latitude ionosphere with GPS, GPSWorld 13(2), 41-46.

Lanyi G.E., Roth T., (1988), A comparison of mapped and measured total ionospheric electron content using global positioning system and beacon satellite observations. Radio Science, 23, 483-492.

Le H., Liu J.Y., Liu L., (2011), A statistical analysis of ionospheric anomalies before 736 M6.0+earthquakes during 2002-2010, Journal of Geophysical Research-Space Physics, doi:10.1029/2010JA015781.

Leick A., (2004), GPS Satellite Surveying, 3rd ed., John Wiley and Sons Inc., New Jersey.

Leonard R.S., Barnes R.A., (1965), Observation of ionospheric disturbances following Alaska earthquake, Journal of Geophysical Research, 70, 1250-1253.

Liao, X., (2000), Carrier phase based ionosphere recovery over a regional area GPS network, M.Sc. Thesis, University of Calgary, Canada.

Lin J., Wu Y., Zhu F., Qiao X., Zhou Y., (2009), Wenchuan earthquake ionosphere TEC anomaly detected by GPS, Chinese Journal of Geophysics-Chinese Edition, 52, 297-300.

Lin J., (2010), Ionospheric total electron content (TEC) anomalies associated with earthquakes through Karhunen-Loeve Transform $(K L T)$, Terrestrial Atmospheric and Oceanic Sciences, 21, 253265.

Lin J., (2012), Ionospheric total electron content seismoperturbation after Japan's March 11, 2011, M=9.0 Tohoku earthquake under a geomagnetic storm; a nonlinear principal component analysis, Astrophysics and Space Science, 341, 251258.

Liperovskaya E.V., Parrot M., Bogdanov V.V., Meister C.V., Rodkin M.V., Liperovsky V.A., (2006), On variations of $f$ oF2 and F-spread before strong earthquakes in Japan, Natural Hazards and Earth System Sciences, 6, 735-739.

Liperovsky V.A., Pokhotelov O.A., Liperovskaya E.V., Parrot M., Meister C.V., Alimov O.A., (2000), Modification of sporadic E-layers caused by seismic activity, Surveys in Geophysics, 21, 449-486.

Liu J.Y., Chen Y.I., Pulinets S.A., Tsai Y.B., Chuo Y.J., (2000), Seismo-ionospheric signatures prior to $M>=6.0$ Taiwan earthquakes, Geophysical Research Letters, 27, 3113-3116.

Liu J.Y., Chen Y.I., Chuo Y.J., Tsai H.F., (2001), Variations of ionospheric total electron content during the Chi-Chi earthquake, Geophysical Research Letters, 28, 1383-1386.

Liu J., Chuo Y., Shan S., Tsai Y., Chen Y., Pulinets S., Yu S., (2004), Pre-earthquake ionospheric anomalies registered by continuous GPS TEC measurements, Annales Geophysicae, 22, 1585-1593.

Liu J.Y., Tsai Y.B., Chen S.W., Lee C.P., Chen Y.C., Yen H.Y., Chang W.Y., Liu C., (2006), Giant ionospheric disturbances excited by the M9.3 Sumatra earthquake of 26 December 2004, Geophysical Research Letters, doi:10.1029/2005GL023963.

Liu J.Y., Chen S.W., Chen Y.C., Yen H.Y., Chang C.P., Chang W.Y., Tsai L.C., Chen C.H., Yang W.H., (2008), Seismo-ionospheric precursors of the 26 december $2006 \mathrm{~m} 7.0$ Pingtung earthquake doublet, Terrestrial Atmospheric and Oceanic Sciences, 19, 75159.

Liu J.Y., Chen Y.I., Chen C.H., Liu C.Y., Chen C.Y., Nishihashi M., Li J.Z., Xia Y.Q., Oyama K.I., Hattori K., Lin C.H., (2009), Seismoionospheric GPS total electron content anomalies observed before the 12 May 2008 M(w)7.9 Wenchuan earthquake, Journal of Geophysical Research-Space Physics, doi:10.1029/2008JA013698.
Liu J.Y., Chen Y.I., Chen C.H., Hattori K., (2010), Temporal and spatial precursors in the ionospheric global positioning system (GPS) total electron content observed before the 26 December 2004 M9.3 Sumatra-Andaman Earthquake, Journal of Geophysical Research-Space Physics, doi:10.1029/2010JA015313.

Liu J.Y., Chen C.H., Lin C.H., Tsai H.F., Chen C.H., Kamogawa M., (2011), Ionospheric disturbances triggered by the 11 March 2011 M9.0 Tohoku earthquake, Journal of Geophysical ResearchSpace Physics, doi:10.1029/2011JA016761.

Mannucci A.J., Wilson B.D., Ewards C.D., (1993), A new method for monitoring the Earth's ionosphere total electron content using the GPS global network, In: Proc. of ION GPS-93, Inst. of Navigation, pp.1323-1332.

Otsuka Y., Ogawa T., Saito A., Tsugawa T., Fukao S. Miyazaki S., (2002), A new technique for mapping of total electron content using GPS network in Japan, Earth Planets and Space, 54, 63-70.

Otsuka Y., Kotake N., Tsugawa T., Shiokawa K., Ogawa T., Effendy, Saito S., Kawamura M., Maruyama T., Hemmakorn N., Komolmis T., (2006), GPS detection of total electron content variations over Indonesia and Thailand following the 26 December 2004 earthquake, Earth Planets and Space, 58, 15965.

Parrot M., Achache J., Berthelier J.J., Blanc E., Deschamps A., Lefeuvre F., Menvielle M., Plantet J.L., Tarits P., Villain J.P., (1993), High-frequency seismo-electromagnetic effects, Physics of the Earth and Planetary Interiors, 77, 65-83.

Plotkin V.V., (2003), GPS detection of ionospheric perturbation before the 13 February 2001, El Salvador earthquake, Natural Hazards and Earth System Sciences, 3, 249-53.

Pulinets S.A., Legen'ka A.D., Gaivoronskaya T.V., Depuev V.K., (2003), Main phenomenological features of ionospheric precursors of strong earthquakes, Journal of Atmospheric and Solar-Terrestrial Physics, 65, 1337-1347.

Pulinets S.A., Boyarchuk K., (2004), Ionospheric Precursors of Earthquakes, Springer, Berlin.

Rao P.V.S.R., Niranjan K., Prasad D.S.V.V.D., Krishna S.G., Uma G., (2006), On the validity of the ionospheric pierce point (IPP) altitude of $350 \mathrm{~km}$ in the Indian equatorial and low-latitude sector, Annales Geophysicae, 24, 2159-2168.

Rios V.H., Kim V.P., Hegai V.V., (2004), Abnormal perturbations in the F2 region ionosphere observed prior to the great San Juan earthquake of 23 November 1977, Monitoring of Changes Related to Natural and Manmade Hazards Using Space Technology, 33, 323-27.

Rozhnoi A., Solovieva M.S., Molchanov O.A., Hayakawa M., (2004), Middle latitude LF (40 kHz) phase variations associated with earthquakes for quiet and disturbed geomagnetic conditions, Physics and Chemistry of the Earth, 29, 589-98.

Schaer S., Gurtner W., Feltens J., (1998), IONEX: The IONosphere Map EXchange format Version 1, Proceedings of the 1998 IGS Analysis Center Workshop, Darmstadt, Germany.

Schaer S., (1999), Mapping and predicting the Earth's ionosphere using the global positioning system, $\mathrm{Ph}$. D. thesis, University of Berne, Switzerland.

Schmidt M., Bilitza D., Shum C.K., Zeilhofer C., (2008), Regional 4-D modeling of the ionospheric electron density, Advances in Space Research, 42, 782-790.

Silina A.S., Liperovskaya E.V., Liperovsky V.A., Meister C.V., (2001), Ionospheric phenomena before strong earthquakes, Natural Hazards and Earth System Sciences, 1, 113-118.

Singh B., Singh O.P., (2007), Simultaneous ionospheric E- and F-layer perturbations caused by some major earthquakes in India, Annals of Geophysics, 50, 111-122. 
Spogli L., Alfonsi L., Cilliers P.J., Correia E., De Franceschi G., Mitchell C.N., Romano V., Kinrade J., Angel Cabrera M., (2013), GPS scintillations and total electron content climatology in the southern low, middle and high latitude regions, Annals of Geophysics, doi:10.4401/ag-6240.

Trigunait A., Parrot M., Pulinets S., Li F., (2004), Variations of the ionospheric electron density during the Bhuj seismic event, Annales Geophysicae, 22, 4123-4131.

Vitinsky Y.I., Kopecky M., Kuklin G.V., (1986), Statistics of sunspot activity (in Russian), Nauka, Moscow.

Yao Y., Chen P., Wu H., Zhang S., Peng W., (2012), Analysis of ionospheric anomalies before the 2011 M-w 9.0 Japan earthquake, Chinese Science Bulletin, 57, 500-510.

Zakharenkova I.E., Krankowski A., Shagimuratov I.I., (2006), Modification of the low-latitude ionosphere before the 26 December 2004 Indonesian earthquake, Natural Hazards and Earth System Sciences, 6, 817-823.
Zakharenkova I., Shagimuratov I., Krankowski A., Lagovsky A., (2007), Precursory phenomena observed in the total electron content measurements before great Hokkaido earthquake of september 25, 2003 ( $M=8.3)$, Studia Geophysica Et Geodaetica, 51, 267-278.

Zakharenkova I., Shagimuratov I., Tepenitzina N., Krankowski A., (2008), Anomalous modification of the ionospheric total electron content prior to the 26 September 2005 Peru earthquake, Journal of Atmospheric and Solar-Terrestrial Physics, 70, 1919-1928.

Zhao B., Wang M., Yu T., Wan W., Lei J., Liu L., Ning B., (2008), Is an unusual large enhancement of ionospheric electron density linked with the 2008 great Wenchuan earthquake?, Journal of Geophysical Research-Space Physics, doi:10.1029/2008JA013613.

Zhou Y., Wu Y., Qiao X., Zhang X., (2009), Ionospheric anomalies detected by ground-based GPS before the Mw7.9 Wenchuan earthquake of May 12, 2008, China, Journal of Atmospheric and Solar-Terrestrial Physics, 71, 959-966. 